\title{
Total Quality Management Application Practices at Assuit University Hospitals
}

\author{
Karima H. Abdel-Hafez.
}

lecturer of Nursing Administration, Faculty of Nursing, Assiut University, Egypt.

\begin{abstract}
Objective: To assess the perception of nurse managers about the application of TQM (Total Quality Management) at Assiut University Hospitals. Subjects and Methods: Research design: A descriptive analytical study design was used to collect data from study subjects. Setting: Data were collected from seven Assiut University hospitals. The Subjects: All nurse managers working at Assiut University Hospitals ( $=$ 393). The instrument : Self-administered questionnaires developed by the researcher were used to collect data, it consists of two parts: First part: nurses managers' personal characteristics information, and Second part: include TQM application practices which divided into 8 practices (74 items). Results: Nurse managers participated in the study perceived that TQM practices are not applied at Assiut University Hospitals. Nurse managers have low level of knowledge about TQM, Nurse managers seek to apply quality to: increase productivity, increase satisfaction, decrease cost, minimize errors, The majority of nurse managers supporting the application of TQM at Assiut University Hospitals, There is a positive correlation between TQM application practices, hospital, educational qualification, and negative correlation between years of experience and TQM application practices. Conclusions: Assiut University Hospital managers must focus their on increasing nurses knowledge and skills to apply TQM at hospital effectively and efficiently. Recommendations: Design an official quality structure for the central quality department, Distributing the quality culture among all hospital personnel through posters, booklets, symposiums, quality magazine, and videos, Preparing a training plan for all nursing personnel to increase their knowledge and skills about TQM. Design an operational plan to implement TQM practices.
\end{abstract}

\section{Keywords: Nurse Managers, TQM \& TQM Implementation Practices.}

\section{Introduction}

Nowadays, health organizations face many challenges that can be classified into four major areas: increases in the cost of health services, rapidly growing technology dependence, pressure on health organizations to decrease costs and improve quality to cope with the international organizations that establish standards and give licenses Chang, Chen, Lan, (2013) Service quality, trust, and finally satisfying patients' needs, a major demand requiring hospitals to maintain high quality services Aiken LH, Sermeus, Van den Heede, et al., (2012) Such challenges force health planners to adopt a system that can manage health care in a measurable way to offer a high quality service, which is the aim of the quality management programs in hospitals Chang, (2014).

The system that can cope with all of these challenges and resolve all health organization's problems is TQM. Total Quality Management is also known as continuous quality improvement (CQI), quality improvement (QI), quality management $(\mathrm{QM})$ and total quality control (TQC) McClellan Mark, Rivlin, (2014).

Quality management has become an important issue in hospitals since the 1980s. The increasing attention to quality is due to government influence, customers and other stakeholders, and hospital management initiatives. A hospital in a TQM environment needs to embrace corporate goals while maintaining its accountability as a contributor to quality patient care. Hospitals around the world have tried to implement Total Quality Management (TQM) with the intention of delivering services in accordance with the expectation of patients and also consolidating their brand equity around quality services. In pursuit of achieving quality services, constant re-engineering of their operations is being done by these organizations through application of TQM concept Al Shdaifat, (2015).

In healthcare system, understanding the practices of TQM implementation not only can provide insights in order to develop approaches to facilitate, TQM practices also improve the successful TQM implementation within local culture Talib (2011) In addition, TQM implementation in medical industry resulted in higher quality care, improved patient satisfaction, better employee morale and increased productivity and profitability Mosadeghrad, \& Ferlie, (2016).

Experts indicate that the key principles of TQM include the following: customer focus, obsession with quality, scientific approach, long-term commitment, teamwork, and continual improvement systems, education, and training, freedom through control, unity of purpose and employee involvement and empowerment Kusumah, (2013). 
The liability of nursing personnel is mainly restricted in the implementation and evaluation of the TQM programs. Nurses represent more than eighty percent of the health workers in any hospital. Sixty percent of nursing personnel work in hospitals. These nurses have played a significant role in the implementation and success of TQM programs Emad Al-Shdaifat (2015).

In order to solve most of the problems in industry, most of the workplace in medical industries have applied the principles and practices of TQM in the recent years. Total quality was a description of the culture, attitude and organization of a company which strives to provide customers with products and services to satisfy their need. In medical industry, quality divided by two components which were content and delivery. Content quality is discussed about the medical outcome that was achieved. Delivery quality reflected individual reflect an individual customer interaction with the medical system. From the review of literature, eight best practices have been identified in TQM implementation namely; (1) top management commitment, (2) human resource management, (3) process management, (4) customer focus and supplier management, (5) material management, (6) quality culture, (7) strategic planning and (8) social responsibility A. Seetharaman., et al., (2015).

In recent years, the interest to apply TQM is increasing to improve internal and external customers' quality of service. Limited research attention has been given to challenges involved in adopting TQM practices in healthcare.

The benefits of successful implementing TQM leads to strengthened competitive position, higher productivity, enhanced market image, elimination of defects and waste, reduced costs and better cost management, higher profitability, improved customer focus and satisfaction, increased customer loyalty and retention, increased job security, improved employee morale and enhanced shareholder and stakeholder value and improved innovative processes

Laxmikumari, (2014)

\section{Significance of the study.}

TQM to contribute to the continuous improvement of health services and to reduce costs through upgrading administrative efficiency and productivity in hospitals. Between the TQM and the HSQ (Health Care Quality) applications, common goals arise; both seek for improving customer satisfaction and productivity through decreasing costs Mine HALIS., (2017) \& Khadour, et al (2016).

It was noticed that more nurse managers suffering from poor quality of services. The general manager of Assiut University Hospitals and her assistants told the researcher that there is a central quality assurance department in Assiut University Hospitals and the need managers need to apply the quality management but there is no system in all hospitals clarifying what are the TQM implementation practices. In addition, there are no researches assessing the implementation of TQM in Assiut University hospitals. Because research on the implementation of Total Quality Management (TQM) has been limited, particularly in developing countries. So, it felt necessary to assess the perception of nurse managers about to what extent Assuit University Hospitals implementing the TQM practices and suggesting an operational plan for applying TQM in the hospitals.

This study seeks to answer the questions

- What is nurse managers level of knowledge about TQM?

- What objectives do nurse managers need to implement TQM?

- To what extent the TQM application in Assiut University Hospitals?

- What are the relationships between TQM practices and personal characteristics of study participants (educational level, years of experience)?

\section{Objectivces Of The Study}

\section{General objective}

To assess the perception of nurse managers about the application of TQM at Assiut University Hospitals.

\section{Specific objectives:}

1. Measure the level of knowledge of nurse mangers about TQM

2. Determine the objectives that nurse managers need to achieve from implementing TQM

3. Identify to what extent the TQM practices are applied at Assiut University Hospitals.

4. Explore the relationship between TQM application practices and nurse managers' personal characteristics (educational level, years of experience).

\section{Subjects \& Methods \\ Research design}

A descriptive analytical study design was used to collect data from study participants.

\section{Setting}

Data were collected from seven Assiut University hospitals.

\section{The Subjects}

All nurse managers working at Assiut University Hospitals $(n=393)$.

The instrument

Self-administered questionnaires developed by the researcher were used to collect data, it consists of two parts 
First part: nurses managers' personal characteristics (age, education level, experience, work hospital), level of knowledge about quality, and objectives of applying TQM and

Second part: include TQM implementation practices which divided into 8 practices (74 items) (Quality culture, Top management, Strategic planning, Human Resource management, Material management, Customer supplier management, Process management, Social responsibility) Statements about TQM were rated on a 3 point Likert scale ranging from (1) I do not know to (3) Applied.

\section{Validity of the instrument}

To ensure the face validity of the instrument, the questionnaire was assessed by 3 experts from teaching staff in health care management from Health Administration Sector at Institute of Public Administration, Saudi Arabia and 2 experts in Nursing Administration, Faculty of Nursing, Assuit university. According to their recommendations, some questions were modified.

\section{Reliability of the study}

A pilot study was carried out on $10 \%$ of nurses. The sample for the pilot study was included within the study. Cronbach alpha was 0.955. According to the feedback from the study participants, changes were made to some items.

\begin{tabular}{|c|c|}
\hline \multicolumn{2}{|c|}{ Reliability Statistics } \\
\hline Cronbach's Alpha & N of Items \\
\hline .955 & 92 \\
\hline
\end{tabular}

\section{Results}

Table (1): Distribution of personal characteristics for the study participants $(n=393)$.

\begin{tabular}{|c|c|c|}
\hline \multirow[t]{2}{*}{ Personal characteristics } & \multicolumn{2}{|c|}{ Nurse managers $(n=393)$} \\
\hline & No. & $\%$ \\
\hline $19-30$ yrs. & 13 & 43.3 \\
\hline $31-35$ yrs. & 13 & 43.3 \\
\hline $36-40$ yrs. & 3 & 10.1 \\
\hline More than 40 yrs. & 1 & 3.3 \\
\hline \multicolumn{3}{|l|}{ Educational qualification: } \\
\hline Bachelor degree of Nursing Science (B.Sc.N) & 351 & 89.3 \\
\hline Master degree & 33 & 8.4 \\
\hline Doctorate degree (Phd) & 9 & 2.3 \\
\hline \multicolumn{3}{|l|}{ Hospital: } \\
\hline Main Assiut University Hospital & 138 & 35.1 \\
\hline Neurosurgery hospital & 31 & 7.9 \\
\hline Woman health hospital & 39 & 9.9 \\
\hline Orman hospital & 47 & 12.0 \\
\hline Pediatric hospital & 67 & 17.0 \\
\hline Urology hospital & 41 & 10.4 \\
\hline Alrajhi hospital & 30 & 7.6 \\
\hline \multicolumn{3}{|l|}{ Years of experience: } \\
\hline $5-10$ yrs. & 164 & 41.7 \\
\hline $11-15$ yrs. & 149 & 37.9 \\
\hline $16-20$ yrs. & 80 & 20.4 \\
\hline
\end{tabular}

\section{Data analysis}

Statistical Package for Social Sciences (SPSS) version 20 was used for data analysis. Percentages and frequencies were used for sample description. Means and standard deviation were used to determine the extent of TQM implementation. Pearson correlation analysis was used for assessment of the inter-relationships among quantitative variables, and Spearman rank correlation for ranked ones. Statistical significance was considered at $\mathrm{p}$-value $<0.05$.

\section{Fieldwork}

An official permission was obtained from the hospital director, the nursing service administration director, before the beginning of data collection. The actual data collection was started in May 2017 and ended in June 2017. The researcher met the nurse managers, explained to them the purpose of the study, a verbal agreement was obtained from each nurse manager to participate in the study,. Those who agreed to participate, were given the questionnaires with full instructions on how to answer it and asked to fill them out.

\section{Ethical Considerations}

The participants' are informed about their rights to participate, refuse, or withdraw at any time. Total confidentiality of any obtained information was ensured. The study maneuver could not entail any harmful effects on participants. 
Table (2): Study participants $(n=393)$ opinions about supporting the application of TQM:

\begin{tabular}{|c|c|c|c|c|}
\hline & Frequency & Percent & Valid Percent & Cumulative Percent \\
\hline Yes & 387 & $\mathbf{9 8 . 2}$ & 98.2 & 98.2 \\
\hline No & 6 & 1.5 & 1.5 & 99.7 \\
\hline Total & 393 & 100.0 & 100.0 & \\
\hline
\end{tabular}

Table (3): Level of knowledge of study participants about TQM:

\begin{tabular}{|c|c|c|c|c|}
\hline & Frequency & Percent & Valid Percent & Cumulative Percent \\
\hline low & 229 & $\mathbf{5 8 . 3}$ & 58.3 & 58.3 \\
\hline moderate & 108 & 27.5 & 27.5 & 85.8 \\
\hline high & 56 & 14.2 & 14.2 & 100.0 \\
\hline Total & 393 & 100.0 & 100.0 & \\
\hline
\end{tabular}

Table (4): Objectives of TQM application.

\begin{tabular}{|c|c|c|c|c|c|c|c|c|}
\hline \multirow{2}{*}{} & \multicolumn{2}{|c|}{ To increase productivity } & \multicolumn{2}{c|}{ To increase satisfaction } & \multicolumn{2}{c|}{ To decrease cost } & \multicolumn{2}{c|}{ To minimize errors } \\
\cline { 2 - 9 } & No. & $\mathbf{\%}$ & No. & $\mathbf{\%}$ & No. & $\mathbf{\%}$ & No. & $\mathbf{\%}$ \\
\hline Yes & 373 & $\mathbf{9 4 . 9}$ & 364 & $\mathbf{9 2 . 6}$ & 370 & $\mathbf{9 4 . 1}$ & 378 & $\mathbf{9 6 . 2}$ \\
\hline No & 20 & 5.1 & 29 & 7.4 & 23 & 5.9 & 15 & 3.8 \\
\hline Total & 393 & 100.0 & 393 & 100.0 & 393 & 100.0 & 393 & 100.0 \\
\hline
\end{tabular}

Table (5): The correlation between Total Quality Management application practices and personal characteristics of nurse managers at Assiut University Hospitals.

\begin{tabular}{|c|c|c|c|c|c|c|c|c|c|c|}
\hline & & & $\begin{array}{l}\text { Quality } \\
\text { culture }\end{array}$ & $\begin{array}{c}\text { Top } \\
\text { management }\end{array}$ & $\begin{array}{l}\text { Strategic } \\
\text { planning }\end{array}$ & $\begin{array}{c}\text { Human } \\
\text { Resource } \\
\text { management }\end{array}$ & $\begin{array}{c}\text { Material } \\
\text { management }\end{array}$ & $\begin{array}{c}\text { Customer } \\
\text { supplier } \\
\text { management }\end{array}$ & $\begin{array}{c}\text { Process } \\
\text { manageme } \\
\text { nt }\end{array}$ & $\begin{array}{c}\text { Social } \\
\text { responsibility }\end{array}$ \\
\hline \multirow[t]{6}{*}{ Spearman's rho } & \multirow[t]{2}{*}{ Hospital } & $\begin{array}{l}\text { Correlation } \\
\text { Coefficient }\end{array}$ & .049 & .061 & $-.046-$ & $-.024-$ & .013 & .045 & .040 & .030 \\
\hline & & $\begin{array}{l}\text { Sig. (2- } \\
\text { tailed) }\end{array}$ & .335 & .225 & .368 & .635 & .793 & .370 & .432 & .557 \\
\hline & \multirow{2}{*}{$\begin{array}{c}\text { education } \\
\text { al } \\
\text { qualificati } \\
\text { on }\end{array}$} & $\begin{array}{l}\text { Correlation } \\
\text { Coefficient }\end{array}$ & .076 & .030 & .048 & $-.007-$ & $-.106-*$ & .031 & .000 & .016 \\
\hline & & $\begin{array}{l}\text { Sig. (2- } \\
\text { tailed) }\end{array}$ & .133 & .555 & .344 & .886 & .036 & .545 & .991 & .746 \\
\hline & \multirow{2}{*}{$\begin{array}{c}\text { years of } \\
\text { experienc } \\
\text { e }\end{array}$} & $\begin{array}{l}\text { Correlation } \\
\text { Coefficient }\end{array}$ & $-.130-^{* *}$ & $-.185-^{* *}$ & $-.155{ }^{* *}$ & $-.268-^{* *}$ & $-.121-^{*}$ & $-.245-^{* *}$ & $-.333-{ }^{* *}$ & $-.021-$ \\
\hline & & $\begin{array}{l}\text { Sig. (2- } \\
\text { tailed) }\end{array}$ & .010 & .000 & .002 & .000 & .017 & .000 & .000 & .672 \\
\hline
\end{tabular}

*. Correlation is significant at the 0.05 level (2-tailed). **. Correlation is significant at the 0.01 level (2-tailed).

Table (6): Mean and Standard deviation of TQM implementation practices.

\begin{tabular}{|c|c|c|c|c|c|}
\hline & N & Minimum & Maximum & Mean & $\begin{array}{c}\text { Std. } \\
\text { Deviation }\end{array}$ \\
\hline Quality culture & 393 & 1.30 & 3.00 & 2.1062 & .32465 \\
\hline Top management & 393 & 1.00 & 3.00 & 2.4268 & .37305 \\
\hline Strategic planning & 393 & 1.00 & 3.00 & 2.0800 & .51211 \\
\hline Human Resources management & 393 & 1.00 & 3.00 & 1.9151 & .41911 \\
\hline Material and financial management & 393 & 1.00 & 3.00 & 1.9630 & .41668 \\
\hline Customer and supplier management & 393 & 1.00 & 3.00 & 1.7557 & .68837 \\
\hline Process management & 393 & 1.00 & 3.00 & 1.8558 & .57583 \\
\hline Social responsibility & 393 & 1.00 & 3.00 & 1.6758 & .51849 \\
\hline
\end{tabular}


Table (7): Coefficient correlation between study participants demographic characteristics, knowledge about TQM, and TQM implementation practices.

\begin{tabular}{|c|c|c|c|c|c|c|c|}
\hline & & & Hospital & $\begin{array}{l}\text { educational } \\
\text { qualification }\end{array}$ & $\begin{array}{c}\text { years of } \\
\text { experience }\end{array}$ & $\begin{array}{c}\text { TQM } \\
\text { implementation } \\
\text { practices }\end{array}$ & $\begin{array}{c}\text { knowledge } \\
\text { level about } \\
\text { TQM }\end{array}$ \\
\hline \multirow{10}{*}{ Spearman's rho } & \multirow[t]{2}{*}{ Hospital } & $\begin{array}{l}\text { Correlation } \\
\text { Coefficient }\end{array}$ & 1.000 & $.055^{*}$ & $-.014-$ & .010 & $.103^{* * *}$ \\
\hline & & Sig. (2-tailed) & . & .050 & .614 & .720 & .000 \\
\hline & \multirow{2}{*}{$\begin{array}{l}\text { educational } \\
\text { qualification }\end{array}$} & $\begin{array}{l}\text { Correlation } \\
\text { Coefficient }\end{array}$ & $.055^{*}$ & 1.000 & $.300^{* *}$ & .019 & $.103^{* *}$ \\
\hline & & Sig. (2-tailed) & .050 & . & .000 & .501 & .000 \\
\hline & \multirow{2}{*}{$\begin{array}{c}\text { years of } \\
\text { experience }\end{array}$} & $\begin{array}{l}\text { Correlation } \\
\text { Coefficient }\end{array}$ & $-.014-$ & $.300^{* *}$ & 1.000 & $-.265-^{* *}$ & $-.025-$ \\
\hline & & Sig. (2-tailed) & .614 & .000 & . & .000 & .370 \\
\hline & \multirow{2}{*}{$\begin{array}{c}\text { TQM } \\
\text { implementati } \\
\text { on practices }\end{array}$} & $\begin{array}{l}\text { Correlation } \\
\text { Coefficient }\end{array}$ & .010 & .019 & $-.265-^{* *}$ & 1.000 & $.215^{* *}$ \\
\hline & & Sig. (2-tailed) & .720 & .501 & .000 & . & .000 \\
\hline & \multirow{2}{*}{$\begin{array}{c}\text { knowledge } \\
\text { level about } \\
\text { TQM }\end{array}$} & $\begin{array}{l}\text { Correlation } \\
\text { Coefficient }\end{array}$ & $.103^{* *}$ & $.103^{* *}$ & $-.025-$ & $.215^{* *}$ & 1.000 \\
\hline & & Sig. (2-tailed) & .000 & .000 & .370 & .000 & 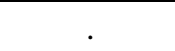 \\
\hline
\end{tabular}

*. Correlation is significant at the 0.05 level (2-tailed). **. Correlation is significant at the 0.01 level (2-tailed).

Table (1): Shows that (86.6\%) of the study participants aged between 19-35, (89.3\%) having B.Sc.N, (35\%) of them working at Main Assiut University Hospital, and (41\%) having 5-10 years of experience.

Table (2): Clarified that approximately all the study participants (98.2\%) support the implementation the TQM at Assiut University Hospitals.

Table (3): Declared that (58.3\%) of the study participants have low knowledge about TQM.

Table (4): Found that approximately all the study participants agreed that the objectives of TQM application are to increase productivity, to increase satisfaction, to decrease cost, to minimize errors (94.9\%, 92.6\%, 94.1\%, 96.2\% respectively).

Table (5): It is noticed from this table that there highly significant negative correlation between Years of experience and TQM application practices (Quality culture Top management, Strategic planning, Resource management, Material management, customer \& supplier management, Process management) (-.130-** $-.185-^{* *}-.155-^{* *}-.268$ ** $\left.-.121-^{*}-.245^{-* *}-.333^{* *}\right)$ respectively, while there is a non-significant negative correlation between Years of experience and TQM application practices (Social responsibility) (-.021-). Also, there is a negative correlation between educational level and resource management and material management (-.007-, -.106*) respectively. Furthermore, there is a negative correlation between Hospital and strategic planning and resource management (-.046-, -.024-) respectively. In addition, it is noticed from the table that there is positive correlation between hospital and quality culture, top management, material management, customer \&supplier management, process management and social responsibility (.049, $.061, .013, .045, .040, .030)$ respectively. There are positive correlation between educational qualification and quality culture, top management, strategic planning, customer \&supplier management, process management and social responsibility $(.076, .030$, $.048, .031, .000, .016)$ respectively.

Table (6): Shows that the mean score for quality culture, top management, strategic planning, human resource management, material and financial management are $(2.1062,2.4268,2.0800,1.9151$, 1.9630) respectively. In addition, the table declared that the mean score customer and supplier management, process management, and social responsibility are $(1.7557,1.8558,1.6758)$.

Table (7): Declared that there is a highly statistical positive correlation between hospital and Knowledge level about quality $\left(.103^{* *}\right)$ and non-statistical positive correlation between hospital and TQM application practices (.010). In addition, there is a highly statistical positive correlation between educational level and Knowledge level about quality $\left(.103^{* *}\right)$ and non-statistical positive correlation between educational level and TQM application practices (.019). Furthermore, there is a highly 
statistical negative correlation between years of experience and TQM application practices $\left(-.265-^{* *}\right)$, and there is a non-statistical negative correlation between years of experience and Knowledge level about quality $\left(-.025^{-* *}\right)$.

\section{Discussion}

The study results clarified that approximately all the study participants $(98.2 \%)$ support the application the TQM at Assiut University Hospitals. This means that the nurse managers participated in the study realized that the application of TQM in hospitals is very important, and the level of supporting the TQM application is very high.

This is goes in the same line with the results of a study of Khadour, et al., (2016) which showed that all factors of TQM practices were high interpretation with the mean of 5.00 above and the range of standard deviation of TQM practices was also very high which is 0.82 to 1.02 . It indicates that TQM practices are important in medical industry because it can lead to the organizational improvements and development of excellence service quality. The majority $(86 \%)$ of the respondents indicated that the hospital had adopted TQM while $14 \%$ indicated that the hospital had not adopted TQM.

It was declared from the study that $(58.3 \%)$ of the study participants have low knowledge about TQM.

Anam Parand \& others (2014) there is a low level of managers knowledge on quality and safety reports, possibly little Boardroom awareness on salient nursing quality issues, and little practice identified to improve quality literacy for the Board.

The study findings Found that approximately all the study participants agreed that the objectives of TQM application are to increase productivity, to increase satisfaction, to decrease cost, to minimize errors (94.9\%, 92.6\%, 94.1\%, 96.2\% respectively).

According to a study done by Hashmi, (2010), successful application of TQM leads to reduced scrap and rework, elimination of defects, reduced level of costs, increased level of productivity and efficiency and better employee morale stated that TQM application will lead to improved products, satisfied employees and customers, reduced costs and improvement in financial performance of an organization.

It is noticed from results of the study, that there is a highly significant negative correlation between Years of experience and TQM application practices (Quality culture Top management, Strategic planning, Resource management, Material management, customer \& supplier management, Process management) (-.130- ${ }^{* *}-.185-^{* *}-.155^{* *}-.268$ $\left.{ }^{* *}-.121-^{*}-.245-^{* *}-.333^{* *}\right)$ respectively, while there is a non-significant negative correlation between Years of experience and TQM application practices (Social responsibility) (-.021-). Also, there is a negative correlation between educational level and resource management and material management (-.007-, -.106$\left.{ }^{*}\right)$ respectively. Furthermore, there is a negative correlation between Hospital and strategic planning and resource management (-.046-, -.024-) respectively. In addition, it is noticed from the table that there are positive correlation between hospital and quality culture, top management, material management, customer \&supplier management, process management and social responsibility (.049, $.061, .013, .045, .040, .030)$ respectively. There are positive correlation between educational qualification and quality culture, top management, strategic planning, customer \&supplier management, process management and social responsibility (.076, .030, $.048, .031, .000, .016)$ respectively.

These findings are not congruent with the study of Md Fauzi Ahmad" et al., (2017) which found that the level of TQM success in Isfahan healthcare organizations was medium. The highest score was achieved in the dimension of "customer management", followed by "leadership" and "employee management". Employee management, information management, customer management, process management and leadership had the most positive effect on TQM success. Using a series of quality management techniques had "synergistic" effect on TQM success.

The study results showed that the mean score for quality culture, top management, strategic planning, human resource management, material and financial management are $(2.1062,2.4268,2.0800,1.9151$, 1.9630) respectively, which indicates that all study participants agreed that TQM is not applied at Assiut University Hospitals. In addition, the table declared that the mean score customer and supplier management, process management, and social responsibility are $(1.7557,1.8558,1.6758)$, which indicates that all study participants to some extent they apply these TQM practices. These findings indicate that the level of TQM application is low, this may be related the low level of knowledge about quality, fear of change, lack of job security, lack of training and motivation, lack of top management support, the concept that TQM application needs more budget.

These findings are matched with the findings of the study conducted by Aiken LH, et al., (2012), who found that there are Five principles of TQM were identified in this study, representing $70 \%$ of the extent of implementing TQM, which consisted of the following: continuous improvement, teamwork, training, top management commitment and customer 
focus, ranging from $41.6 \%$ to $53.9 \%$ of 40 items. Customer focus was the most implemented principle (mean 53.9\%), and continuous improvement was the least implemented (mean 41.6\%).

These results were supported by Lee, Khong, Ghista, Mohammad Mosadegh Rad (2008) who found that implementation of TQM was very low and was affected by management process, focus on customers, leadership and management. Process management was the highest level in application, and the lowest was focus on employees. This is consistent with the findings of Sadikoglu, Olcay, (2014) who extracted three principles of TQM: teamwork, customer focus and continuous improvement. These three principles explained $58 \%$ of the variance with 12 items. The highest implemented principle was continuous improvement (3.36 out of 5), followed by customer focus (3.05) and finally teamwork (2.59).

These results were not supported by Al-Omar, (2002) who identified four principles: continuous improvement decision-making depending on the data, top management commitment and customer focus. These principles altogether explained $65 \%$ of the variance with 26 items. Customer focus was the highest implemented principle (mean 3.78 out of 5), and the least implemented principle was decisionmaking depending on the data (mean 3.46 out of 5).

The findings of the study revealed that there is a highly statistical positive correlation between hospital and Knowledge level about quality $\left(.103^{* *}\right)$ and nonstatistical positive correlation between hospital and TQM implementation practices (.010). In addition, there is a highly statistical positive correlation between educational level and Knowledge level about quality $\left(.103^{* *}\right)$ and non-statistical positive correlation between educational level and TQM implementation practices (.019). Furthermore, there is a highly statistical negative correlation between years of experience and TQM implementation practices $\left(-.265^{-* *}\right)$, and there is a non-statistical negative correlation between years of experience and Knowledge level about quality $\left(-.025-^{* *}\right)$.

The findings of the study were congruent with results of Emad A. Al-Shdaifat, (2015) who indicates that there were statistically significant positive correlations between continuous improvement, human resource management and top managerial commitment with the availability of TQM department as the P-values was 0.001, 0.015, 0.001 and 0.001, respectively. Demographic variables (gender, age, education, experience department) did not show any significant difference with the implementation of TQM principles. This is also consistent with the study by Taamneh, (2012) who found a significant difference related to education level, experience, and the academic specialty was observed.
These findings are not consistent with the findings of Pourrajab, (2012) who found that there was no relationship between the extent of implementing TQM and socio-demographic variables (gender, age, education level, experience, work department, and number of patients served daily) except for the availability of a TQM unit. In other words, the degree of TQM implementation was increased by the availability of a quality unit. There is a significant difference related to the availability of quality unit and the extent of implementing TQM.

\section{Conclusions}

The present study concluded that eight TQM application practices in hospitals: Quality culture, Top management, Strategic planning, Human Resource management, Material management, Customer supplier management, Process management, Social responsibility are poorly implemented in Assiut University hospitals. The study also found significant difference related to socio-demographic variables (education qualification, experience, work hospital) in hospitals that have an ineffective central quality department. The degree of TQM application is improved through and effective operation of a quality department.

\section{Recommendations}

1. Design an official quality structure for the central quality department including department manager, assistant, quality coordinators, quality facilitators, quality team managers, and quality team members. So, distributing the tasks for them. And training them about TQM implementation practices.

2. Preparing a quality manual and distributing it to all hospital departments.

3. Preparing quality policy and procedure manual and distributing it among all hospital departments.

4. Distributing the quality culture among all hospital personnel through posters, booklets, symposiums, quality magazine, and videos.

5. Preparing a training plan for all nursing personnel to increase their knowledge and skins about TQM.

6. Provide incentives for nursing personnel for motivating them to perform the TQM practices effectively and efficiently.

7. Design an operational plan to implement TQM practices.

8. Further studies should be conducted to assess the facilitators and inhibitors of applying TQM at Assiut University Hospitals. 


\section{References}

1. Aiken L., Sermeus W., Van den Heede K., (2012): Patient safety, satisfaction, and quality of hospital care: cross sectional surveys of nurses and patients in 12 countries in Europe and the United States 2012; 344.

2. Aiken L., Sermeus W., Van den Heede K., (2012): Patient safety, satisfaction, and quality of hospital care: cross sectional surveys of nurses and patients in 12 countries in Europe and the United States 2012; 344.

3. Al Shdaifat, E., (2015): Implementation of total quality management in hospitals. Journal of Taibah University

4. Al-omar B., (2002): The extent to which TQM principles are implemented in Riyadh city hospitals: from the perspectives of nurses. J Public Adm 2002; 24(2): 307e352.

5. Chang C., Chen S., Lan Y., (2013): Service quality, trust, and patient satisfaction in interpersonal-based medical service encounters. BMC Health Serv Res 2013; 13(1): 22.

6. Chang T., (2014): Fuzzy VIKOR method: a case study of the hospital service evaluation in Taiwan. Inf Sci 2014; 271(0): 196e212. Cummings $\mathrm{T}$, Worley C. Organization development and change: cengage learning; 2014.

7. Emad A., Al-Shdaifat (2015): Implementation of total quality management in hospitals. Journal of Taibah University Medical Sciences. Volume 10, Issue 4, December 2015, Pages 461-466

8. Halis M., Mohammed R., Twati, Halis M., (2017): Total quality management implementation in the healthcare industry: Findings from Libya Management Issues in Healthcare System 3 (2017) 4-21

9. Hashmi, K., (2010): Introduction and implementation of total quality management (TQM). Available at: https://www.isixsigma.com/methodology/totalqualitymanagement $\% 20 \mathrm{tqm} /$ introduction-andimplementation-total-quality management-tqm/ [Accessed: 22 december 2014].

https://doi.org/10.1016/j.jtumed.2015.05.004

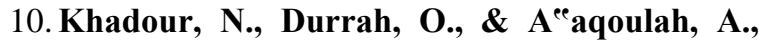
(2016): The Role of Applying Total Quality Management in Improving Incentives: A Comparative Study between Jordanian and United Arab Emirate Hospitals. International journal of Business and Management, 11(11), pp. 126-138.

11. Kusumah L., (2013): The essential factors of TQM principles implementation in small industries in Indonesia. J US - China Public Adm 2013; 10(12).
12. Laxmikumari Dr Y., Vijay Kumar Dr. V., Venkata Ramana TQM (2014): A Quality and Performance Enhancer Research Inventy: International Journal of Engineering And Science Vol.4, Issue 8 (August 2014), PP 91-94 Issn (e): 2278-4721, Issn $\quad$ (p):2319-6483, www.researchinventy.com

13. Lee P., Khong P., Ghista D., Mohammad Mosadegh Rad A., (2018): The impact of organizational culture on the successful implementation of total quality management. TQM Mag 2008; 18(6): 606e625.

14. McClellan Mark, Rivlin A., (2014): Improving health while reducing cost growth what is possible?. Washington, DC: Engelberg Center for Health Care Reform at Brookings; April 2014.

15. Md Fauzi Ahmad, Neo Yeong Ting, Nik Hisyamudin Muhd Nor, Chan Shiau Wei, Mohd Fahrul Hassan, Nor Aziati Abdul Hamid (2017): Total Quality Management Practices In Malaysia Healthcare Industry: A Survey Result, International Journal of Supply Chain Management, Excelingtech , 2, 332, Issn:20513771

16. Mosadeghrad, A., \& Ferlie, E., (2016): Total Quality Management in Healthcare in Ortenblad, A. Abrahamson Lofstrom, C. \& Sheaff, R., Management innovations for healthcare organizations: adopt, abandon or adapt?, Routledge.

17. Parand A., Dopson S., Renz A., (2014): The role of hospital managers in quality and patient safety: a systematic review. BMJ. 2014;4:e005055. doi:10.1136/bmjopen-2014005055

(http://dx.doi.org/

10.1136/bmjopen2014005055).

18. Pourrajab M., Basri R., Daud S., Asimiran S., Mousavy S., (2012): The relationship between level of total quality management (TQM) and the level of culture of teaching and learning (COTL) in school. Int J Res Manag Technol 2012; 2(3): 319.

19. Sadikoglu E., Olcay H., (2014): The effects of total quality management practices on performance and the reasons of and the barriers to TQM practices in Turkey. Adv Decis Sci 2014; 2014: 17.

20. Seetharaman A., Raj J., SaSeetharaman S., (2015): http://dx.doi.org/10.15722/jds.13.8.201508.27

The Implementation of Total Quality Management in Controlling the Cost of Manufacturing Received: June 02, 2015. Revised: July 25, 2015. Accepted: August 15, 2015. 
21. Taamneh M., (2012): Total quality management in public sector (Ministry of Health). Abhath AlYarmouk 2012; 17(1).

22. Talib F., Rahman Z., \& Azam M., (2011)Best Practices of Total Quality Management Implementation in Health Care Settings, Health Marketing Quarterly, 28:232-252, 2011. 
Vol, (5) No, (12) December 2017 